\title{
SURVEY OF IndianA AgRiCUlTURAL LAW
}

\author{
BRIANNA J. SCHROEDER ${ }^{*}$
}

\section{INTRODUCTION}

Modern agricultural producers are not like the farms of yesteryear. Farmers today use high tech machinery outfitted with GPS and precision equipment. Producers also must contend with the changing contours of federal, state, and local law. This presentation at the IU Symposium addressed four areas farmers must face to be successful year after year.

\section{RIGHT TO FARM ACT}

In 2018 and 2019, large livestock operations across the country were targeted by lawsuits. ${ }^{1}$ Generally, these suits involve a nearby landowner or neighbor who sues the livestock farmer for common law torts such as nuisance, negligence, and trespass. ${ }^{2}$ All fifty states have enacted some sort of Right to Farm Act ("RTFA"). This includes North Carolina and Indiana - the two states which were the focus of this Symposium presentation.

First, North Carolina merits special attention. Over 500 plaintiffs filed suits against Murphy-Brown, LLC, a subsidiary of Smithfield Foods, Inc. ${ }^{4}$ The lawsuits alleged eighty-nine different swine farms populated by pigs owned by Murphy-Brown were a nuisance. ${ }^{5}$ The neighbors argued the odor, flies, and other fallout from the farms negatively impacted their lives. ${ }^{6}$ The plaintiffs contended Murphy-Brown refused to use new waste management technology to reduce odors. ${ }^{7}$ They pointed to a 1999 agreement in which Smithfield agreed to eliminate

* Janzen Agricultural Law, LLC.

1. See generally April Simpson, Neighbors Suing Over Pig Fumes Spur 'Right-to-Farm' Push, The Pew Charitable Trusts (May 22, 2019), https:/www.pewtrusts.org/en/research-andanalysis/blogs/stateline/2019/05/22/neighbors-suing-over-pig-fumes-spur-right-to-farm-push [https://perma.cc/BS5X-4R6M].

2. See generally id.

3. Alexandra Lizano \& Elizabeth Rumley, States' Right-to-Farm Statutes, The NAT'L AGRIC. LAW CTR. (June 6, 2019), https://nationalaglawcenter.org/state-compilations/right-to-farm/ [https://perma.cc/2YG7-VWXC].

4. Erica Hellerstein, Opening Statements Begin in the First Case Against Pork Giant Murphy-Brown, INDYwEEK.COM (Apr. 4, 2018), https://indyweek.com/news/archives/openingstatements-begin-first-case-pork-giant-murphy-brown/ [https://perma.cc/67BM-RJ9C] [hereinafter Opening Statements Begin].

5. John Murawski, House Passes Limited Hog Farm Liability Bill, THE News \& OBSERVER (Apr. 10, 2017), https://www.newsobserver.com/news/business/article143849889.html.

6. Erica Hellerstein, How Smelly Is Too Smelly? What We Learned From the First Two Days of the Murphy-Brown Hog Nuisance Trial., INDYwEEK.COM (Apr. 5, 2018), https://indyweek.com/ news/archives/smelly-smelly-learned-first-two-days-murphy-brown-hog-nuisance-trial./ [https://perma.cc/766J-BQSW].

7. $I$. 
a manure spraying system in Missouri after a lawsuit in that state. ${ }^{8}$ The Missouri resolution also included covering open lagoons, but Smithfield did not implement that change in North Carolina. ${ }^{9}$ The actual farmers - the owners of the physical farms and the people in charge of caring for the pigs - were not named in the lawsuits. ${ }^{10}$ Instead, the lawsuits focus on Smithfield, a meat-processing company wholly owned by a Chinese company. ${ }^{11}$

Before trial, the federal district court ruled on summary judgment that North Carolina's Right to Farm Act ${ }^{12}$ did not apply as a matter of law. ${ }^{13}$ The court reasoned that for the North Carolina RTFA to apply, the agricultural operation must have become a nuisance because of changed conditions in the locality outside the agricultural operation. ${ }^{14}$ The court noted the plaintiffs had produced evidence they or their families had lived on the affected properties before the subject swine farms began operations. ${ }^{15}$ Smithfield argued that, nonetheless, the area around the farms had significantly changed over the years with a drastic increase in population. ${ }^{16}$ The court concluded that for RTFA to apply, it must be on account of changed conditions in the locality that the agricultural operation has become a nuisance. ${ }^{17}$ The court held the plaintiffs' nuisance claims had nothing to do with changed conditions in the area, and therefore decided the RTFA would not bar those claims. ${ }^{18}$

As of April 2019, juries had handed down five verdicts against Smithfield. In the first trial, the jury awarded ten plaintiffs a total of $\$ 50$ million in punitive damages and $\$ 750,000$ in compensatory damages for damages allegedly caused by the nearby hog farm. ${ }^{19}$ Testimony during the case alleged Murphy-Brown should have done more to modernize its manure management, like confined feeding operations ("CFOs") in other states have done. ${ }^{20}$ The plaintiffs' attorney said that despite a court order in Missouri to cover lagoons and use a different

\footnotetext{
8. Opening Statements Begin, supra note 4.

9. Id.

10. Murawski, supra note 5.

11. Sarah Willets \& Leigh Tauss, Smithfield Foods Says It Will Cover Its Lagoons. Critics
} Say That's Just Lipstick on a Pig., INDYwEEK.COM (Oct. 31, 2018), https://indyweek.com/news/ northcarolina/smithfield-foods-cover-its-lagoons/ [https://perma.cc/RN8J-ELSQ].

12. N.C. GEN. STAT. § 106-701 (2019).

13. In re NC Swine Farm Nuisance Litig. No. 5:15-CV-00013-BR, 2017 U.S. Dist. LEXIS 185089 , at $* 27$ (E.D.N.C. Nov. 8, 2017).

14. Id. at $* 25-27$.

15. Id. at $* 25$.

16. Id.

17. Id. at $* 26$.

18. Id. at $* 27$.

19. Erica Hellerstein, Plaintiffs Awarded $\$ 50$ Million in Landmark Smithfield Hog Nuisance Case, INDYWEEK.COM (Apr. 26, 2018), https://indyweek.com/news/archives/breaking-plaintiffsawarded-50-million-landmark-smithfield-hog-nuisance-case/ [https://perma.cc/PL44-V53S] [hereinafter Plaintiffs Awarded \$50 Million].

20. Opening Statements Begin, supra note 4. 
spray system, the farms in North Carolina use open air lagoons and outdated spray technologies. ${ }^{21}$ Smithfield's attorney countered that the jury should focus on the farm at issue, not methods used in other states where temperatures and lagoon construction rules were different. ${ }^{22}$ Punitive damages in North Carolina are capped by state law at three times the amount of compensatory damages. ${ }^{23}$ The plaintiffs' attorneys argued that applying the damages cap was unconstitutional, but the judge rejected that argument and reduced the award to $\$ 325,000$ per plaintiff. $^{24}$

Over the next three trials, juries awarded millions more against Smithfield. ${ }^{25}$ Smithfield has appealed to the Court of Appeals for the Fourth Circuit. ${ }^{26}$ Agricultural groups have joined the appeal, arguing the North Carolina RTFA protects farmers against lawsuits like these. ${ }^{27}$

Could we see similar verdicts here in Indiana? Unlikely. Indiana also has a RTFA. ${ }^{28}$ The Indiana Right to Farm Act protects farmers' ability to produce food. ${ }^{29}$ It is a statute designed "to conserve, protect, and encourage the development and improvement of its agricultural land for the production of food and agricultural products." ${ }^{30}$ The General Assembly noted that when nonagricultural land uses extend into traditionally agricultural areas, agricultural operations often become targets for lawsuits. ${ }^{31}$ This discourages farmers from investing in agricultural improvements. Put another way: The Act protects the development of agricultural land to grow food.

The protection is aimed to shield against competing nonagricultural land uses. $^{32}$ One key consideration in any Indiana RTFA case is what kind of damages the plaintiffs allege occurred because of the defendant farm. Are the damages nonagricultural? Allegations of decreased house value, odor, flies, or truck traffic are nonagricultural. The Court of Appeals made this clear in Parker v. Obert's

21. Id.

22. Id.

23. N.C. Gen. Stat. § 1D-25 (LexisNexis 2019).

24. Erica Hellerstein, Attorneys Suing Murphy-Brown Say the Punitive Damages Cap is Unconstitutional, INDYWEEK.COM (May 3, 2018), https://indyweek.com/news/archives/attorneyssuing-murphy-brown-say-punitive-damages-cap-unconstitutional/ [https://perma.cc/4EQC-2RLB]; Erica Hellerstein, Judge Britt Reduces Murphy-Brown's Punitive Damages to \$3.25 Million, INDYWEEK.COM (May 7, 2018), https://indyweek.com/news/archives/judge-britt-reduces-murphybrown-s-punitive-damages-3.25-million/ [https://perma.cc/F362-D4EX].

25. Michael Phillis, Hog Waste Stench Award Threatens Agriculture, 4th Circuit Told, LAw360 (Mar. 6, 2019), https://www.law360.com/articles/1135730/hog-waste-stench-awardthreatens-agriculture-4th-circ-told [https://perma.cc/LU28-U9KV].

26. $I d$.

27. $I d$.

28. IND. CODE $\S 32-30-6-9$ (2002).

29. § 32-30-6-9.

30. $\S 32-30-6-9(\mathrm{~b})$.

31. § 32-30-6-9(b).

32. See generally id. 
Legacy Dairy, $L L C^{33}$ and TDM Farms, Inc. v. Wilhoite Family Farm, LLC. ${ }^{34}$ On the other hand, allegations of agricultural damages (i.e., a lawsuit between two farms) could take away the protections under the Right to Farm Act. In TDM Farms, the court explained the Act would not bar a suit by one hog farmer against another hog farmer related to a swine disease spread from one farm to another. ${ }^{35}$ Because the basis or reason for the suit was agricultural damages (dead pigs) rather than nonagricultural (alleged devaluation of house), the Right to Farm Act had no role to play. ${ }^{36}$

Recently, the Indiana Court of Appeals again considered the RTFA. ${ }^{37}$ In Himsel v. Himsel, a farm family decided to build a new hog farm on some of their existing farmland. ${ }^{38}$ They applied for and received the necessary permission from the county and the state to build the farm. ${ }^{39}$ The farmers built the barns and populated them with pigs in October 2013. ${ }^{40}$ That month, a group of area neighbors filed a lawsuit against the farmers and their integrator, alleging the farm was a nuisance, was being operated negligently, and caused odors that constituted a trespass. ${ }^{41}$ The trial court initially ruled in favor of the neighbors, allowing the case to proceed to trial. ${ }^{42}$ This went against years of Indiana Right to Farm Act court decisions and the Act itself. The Indiana Agricultural Law Foundation ("IALF"), Indiana Pork Producers Association, and Hendricks County filed briefs in support of the farmers and asked the trial court to reconsider. ${ }^{43}$ The court agreed with the farmers and their supporters and reversed its initial order, this time entering judgment in favor of the farmers. ${ }^{44}$ The neighbors appealed to the Court of Appeals. ${ }^{45}$

On appeal, the neighbors argued the farmers failed to meet the Act's requirements. ${ }^{46}$ The neighbors claimed the CFO would have been a nuisance at

33. Parker v. Obert's Legacy Dairy, LLC, 988 N.E.2d 319, 323-24 (Ind. Ct. App. 2013).

34. TDM Farms, Inc. V. Wilhoite Family Farm, LLC, 969 N.E.2d 97, 111 (Ind. Ct. App. 2012).

35. Id. at 104 .

36. Id. at 110-11.

37. See Himsel v. Himsel, 122 N.E.3d 935 (Ind. Ct. App. 2019). Plaintiffs filed a petition for rehearing on May 22, 2019, supported by three amicus curiae briefs. Defendants and the amici supporting them filed briefs opposing the petition for rehearing on June 6, 2019. The rehearing was ultimately denied on July 12, 2019. Himsel v. Himsel, 2019 Ind. App. LEXIS 314 (Ind. Ct. App. 2019).

38. Himsel, 122 N.E.3d at 939.

39. Id. at 940 .

40. Id. at 941 .

41. Id. at $941-45$.

42. Id. at 941 .

43. Id. at 941 n.3.

44. Id. at 941 .

45. Id. at 942 .

46. Id. 
the time farming began in that area. ${ }^{47}$ Since the neighbors built their homes before the hog farm existed, they argued the Right to Farm Act should not apply. ${ }^{48}$ The neighbors also argued the odor from the farm was a "trespass" and that the county was negligent for siting the barns too close to the neighbors' homes. ${ }^{49}$ Finally, the neighbors alleged that the Act violated the Indiana and U.S. constitutions by providing privileges to farmers that did not apply to their non-farming neighbors..$^{50}$ The Court of Appeals rejected all of neighbors' arguments. ${ }^{51}$

The farmers and the amici argued - and the Court agreed - that the Act preserves farmland by protecting farmers against nuisance lawsuits even if the modern farm arrives after the neighbors had already settled into the area. ${ }^{52}$ The change from cropland to livestock farming is not a statutorily "significant change" which would remove the Act's protections. ${ }^{53}$ The farm was used for agricultural purposes at least as early as 1941, and neighbors' non-farming land use began well after $1941 .^{54}$ The neighbors knowingly built their homes in an agricultural area. ${ }^{55}$ That was enough for the Act to apply. ${ }^{56}$ The Court also rejected neighbors' attempt to "repackage" their nuisance claim as one for "trespass" or "negligent siting." 57

Finally, the Court held that the Indiana Right to Farm Act is constitutional. ${ }^{58}$ The Act does not violate the Open Courts Clause ${ }^{59}$ in the Indiana Constitution because the Clause does not require the law to provide a remedy for every wrong. ${ }^{60}$ The Open Courts Clause merely prevents "the legislature from arbitrarily . . . denying access to the courts. ${ }^{.61}$ Likewise, the Act does not run afoul of the state or federal "takings" clauses because Plaintiffs were not deprived of all the value of their properties. ${ }^{62}$ Lastly, the Right to Farm Act does not violate the Privileges and Immunities Clause of the Indiana Constitution, because the Act itself spells out the rationale for treating farmers differently than their nonfarming neighbors. ${ }^{63}$ The purpose of the Act is to protect and encourage the

47. Id. at 943 .

48. $I d$.

49. Id. at $944-45$.

50. Id. at 945 .

51. Id. at $944-49$.

52. Id. at 945 .

53. Id. at 944 .

54. Id.

55. Id.

56. Id.

57. Id. at 945 .

58. Id. at 946 .

59. Ind. Const. art. I, $\S 12$.

60. Himsel, 122 N.E.3d at 946.

61. Id. at $945-46$ (emphasis added).

62. Id. at 946-48.

63. Id. at 948-49. 
development of agricultural land for the production of food. ${ }^{64}$ Plaintiffs filed a petition for rehearing, which was denied. Plaintiffs then requested that the Indiana Supreme Court accept transfer for the case, but the Court denied the request for transfer on February 21, 2020, leaving the Court of Appeals' decision in place. ${ }^{65}$

The Indiana and North Carolina right to farm statutes are worded differently. Likewise, courts have interpreted and applied those acts in distinct ways. The Indiana RTFA appears to give more security to farmers than the North Carolina statute.

\section{CONSUMERS AS THE NEW REGULATORS}

In addition to traditional rules and regulations, agricultural operators also now must consider consumer demands. These changing demands and trends function almost as a new form of regulation.

One example is that of cage-free eggs. Conventional egg hens live in climatecontrolled stacked rows of cages with continual access to food and water. ${ }^{66}$

The cage has wire mesh floors that allow manure to drop through to a belt below, which keeps manure away from the birds, as well as their eggs, food and water. After a hen lays an egg, it gently rolls off the slightly-sloped [sic] mesh flooring onto an egg-collection belt. The belt moves the egg to processing, where it is checked for imperfections, cleaned and packaged. ${ }^{67}$

In the past twenty years, the United States has seen a movement toward "cage-free" eggs. ${ }^{68}$ These hens have the ability "to roam vertically and horizontally in indoor houses and have access to food and water." ${ }^{199}$ There are various types of systems, but they all allow "hens to exhibit natural behaviors and include enrichments such as scratch areas, perches, and nests." ${ }^{70}$ Birds also tend to peck more aggressively at each other and exhibit higher rates of cannibalism. ${ }^{71}$ In a cage-free system, like a traditional system, belts keep manure away from the birds and eggs. ${ }^{72}$ Hens lay eggs in nest boxes and the eggs roll off into a collection system for packaging. ${ }^{73}$

In response to consumer and activist pressure, numerous restaurants, grocery

64. Id. at 949 .

65. Himsel v. 4/9 Livestock, LLC, 2020 WL 888718 (Ind. 2020).

66. Choices in Hen Housing, UEP CERTIFIED RESOURCES (2019) https://uepcertified.com/ choices-in-hen-housing/ [https://perma.cc/2CGW-4RY9] [hereinafter Choices in Hen Housing].

67. Id.

68. Id.

69. Id.

70. Id.

71. United Egg Producers, Certified Cage Guidelines, Animal Husbandry Guidelines FOR U.S. EGG-LAYING Flocks 26 (2017).

72. Choices in Hen Housing, supra note 66.

73. Id. 
stores, and retailers have made commitments to use only cage-free eggs in the coming years. ${ }^{74}$ Burger King, Hormel, Whole Foods, Starbucks, McDonald's, Panera Bread, TGI Friday, Aramark, Einstein Bagels, and Sodexo are just the tip of the iceberg. ${ }^{75}$ As these companies promise consumers that soon they will only use cage-free eggs, those demands flow back to processors and farmers. ${ }^{76}$ In a 2015 study, eggs from a large cage-free house cost about 36\% more to produce than eggs from traditional cages. ${ }^{77}$ Farmers have to purchase new equipment and retrofit their barns for cage-free production. ${ }^{78}$ It looks like consumers and big food companies may be willing to accept that increase.

Farmers don't only have to contend with changing consumer preferencenew state laws can affect producers across the country. For example, in California, voters have passed two propositions which impact egg farms around the country. ${ }^{79}$ In 2008, voters passed Proposition 2, which prohibited confinement of animals in a manner that prevented them from turning around, lying down, standing up, and stretching their wings. ${ }^{80}$ The California State Legislature passed a law which banned the sale of imported eggs that did not comply with Proposition $2 .^{81}$ Ten years later, in 2018, California voters passed Proposition 12, which defined minimum space requirements for hens, sows, and veal calves, and banned the sale of eggs or meat from animals from farm systems which do not meet the minimum space requirements. ${ }^{82}$ The new law essentially required that all eggs sold in California come from cage-free systems-regardless of where those eggs were laid. ${ }^{83}$

Similarly, Massachusetts voters passed a ballot measure requiring that any pork, veal, or eggs sold in the state must be derived from animals raised with

74. Tracie Cone, Burger King Makes Cage-Free Eggs, Pork Promise, The OKLahoman (May 1, 2012, 12:00 AM), https://oklahoman.com/article/3671476/burger-king-makes-cage-freeeggs-pork-promise [https://perma.cc/SPW4-AABJ].

75. Id.

76. $I d$.

77. W.A. Matthews \& D.A. Sumner, Effects of Housing System on the Costs of Commercial Egg Production, 94 Poultry ScIEnce 552, 552 (2015).

78. See generally id.

79. Cal. Proposition 2 (2008), https://vig.cdn.sos.ca.gov/2008/general/text-proposedlaws/text-of-proposed-laws.pdf\#prop2 [https://perma.cc/8GWV-EHB6]; Cal. Proposition 12 (2018), https://vig.cdn.sos.ca.gov/2018/general/pdf/topl.pdf\#prop12 [https://perma.cc/JS22-2CZA]. Both were codified as the Prevention of Farm Animal Cruelty Act. CAL. HeAlth \& SAFETy CODE $\S \S$ 25990-94 (West 2018).

80. Cal. Proposition 2 (2008), https://vig.cdn.sos.ca.gov/2008/general/text-proposedlaws/text-of-proposed-laws.pdf [https://perma.cc/8GWV-EHB6] (codified as CAL. HEALTH \& SAFETY CODE $\S \S 25990(a), 25991($ e)(1) (West 2008)).

81. See Cal. Health \& Safety Code $§ 25996$ (West 2011).

82. Cal. Proposition 12 (2018), https://vig.cdn.sos.ca.gov/2018/general/pdf/topl.pdf [https://perma.cc/JS22-2CZA] (codified as CAL. HeAlth \& SAFETy CodE §§ 25990-94 (West 2018)).

83. Id.; see also CAL. HeAlth \& SAFEty Code $§ 25996$ (West 2011). 
space to turn around and lie down without touching an enclosure. ${ }^{84}$ Washington State passed a similar measure in $2019 .{ }^{85}$

The California and Massachusetts laws triggered several lawsuits, culminating in State of Missouri et al. v. State of California, a suit brought by a band of egg-producing states, including Indiana ${ }^{86}$ That lawsuit asked the United States Supreme Court to strike down California's law, arguing the law was preempted by the federal Egg Products Inspection Act, and violated the Interstate Commerce Clause of the U.S. Constitution. ${ }^{87}$ In short, the lawsuit contended it was illegal for California to make laws that dictated how farmers in Indiana raised egg-laying hens. ${ }^{88}$ The states also argued California law would cause higher egg prices for all consumers, regardless of whether they lived in California. ${ }^{89}$

The Supreme Court asked the U.S. Solicitor General to weigh in on whether the Supreme Court should take the case..$^{90}$ On November 30, 2018, the Solicitor General submitted an amicus curiae brief arguing the California egg laws were not preempted by federal law because the Egg Products Inspection Act did not address confinement conditions for egg-laying hens. ${ }^{91}$ Further, the Solicitor General continued, none of the plaintiff states' sovereign functions were jeopardized by the egg laws. ${ }^{92}$ Egg producers may bring suit, but the Solicitor General opined that it was improper for the states themselves to be parties to the suit. ${ }^{93}$ The brief also maintained that if the cost of eggs rose, it was not solely because of the California egg laws. ${ }^{94}$ The Solicitor General suggested the case would be more appropriate for a district court to sort out complex factual questions. $^{95}$

On January 7, 2019, the Supreme Court declined to take up the states' lawsuit challenging the California egg laws. ${ }^{96}$ The Court also refused to hear a lawsuit led by Indiana ${ }^{97}$ which challenged the Massachusetts egg laws on interstate

84. Mass. Ballot Measure Question 3 (2016), https:/www.sec.state.ma.us/ele/elepdf/ IFV_2016.pdf [https://perma.cc/XSB3-H36E] (codified as Prevention of Farm Animal Cruelty Act, MASS. GEN. LAwS S51A, $\S \S 1-10$ (2017)).

85. Washington Wholesome Eggs and Eggs Products Act, WAsh. Rev. CodE $\S$ 69.25.010-69.25.930 (2019).

86. Proposed Bill of Complaint, Missouri v. California 139 S. Ct. 859 (2019) (No. 22O148).

87. Id. at $10-11,22-23$.

88. See id. at $1-2,23$.

89. Id. at 1.

90. See Brief for the United States as Amicus Curiae at 1, Missouri v. California, $139 \mathrm{~S}$. Ct. 859 (2018) (No. 22O148).

91. Id. at 7.

92. Id. at 15 .

93. Id. at 16-18.

94. Id. at 10-13.

95. Id. at 7 .

96. See Missouri v. California, 139 S. Ct. 859 (2019).

97. Alabama, Arkansas, Indiana, Louisiana, Missouri, Nebraska, North Dakota, Oklahoma, Texas, Utah and Wisconsin joined both lawsuits. West Virginia and South Carolina joined only in 
commerce grounds. ${ }^{98}$ Justice Thomas would have heard the matters. ${ }^{99}$

On the other side of the coin, legislators in Iowa passed a new law in 2018 requiring any retailers participating in the federal supplemental food program for women, infants, and children (WIC) to sell conventional eggs if they sell eggs from chickens housed in a cage-free, free-range, or enriched colony cage environment. ${ }^{100}$ The bill does not require a store to stock conventional eggs if selling eggs is not part of its normal business. ${ }^{101}$ A store also would not need to stock conventional eggs if, prior to January 1,2018 , the store only sold specialty eggs. ${ }^{102}$

"Plant-based dairy" is another new area impacting traditional agricultural producers. For years, consumer groups and industry representatives (from dairy and plant milk companies) have raised questions over what can be marketed as "milk." In 2017, United States Senator Tammy Baldwin introduced the DAIRY PRIDE Act (Defending Against Imitations and Replacements of Yogurt, Milk, and Cheese to Promote Regular Intake of Dairy Everyday Act), which would have compelled the FDA to enforce its milk standard of identity. ${ }^{103}$ The Act has not yet passed.

In 2018, the FDA proposed enforcing its own labeling rules for milk, which could prevent producers of almond milk and oat milk from continuing to use the term. ${ }^{104}$ The proposed rule received over 14,000 comments; the comment period ended January 28, 2019. ${ }^{105}$ In the meantime, plant milk producers scored a key victory in the courts. The Court of Appeals for the Ninth Circuit ruled that calling almond milk "milk" is not deceptive, upholding the dismissal of a consumer's lawsuit. ${ }^{106}$ The Court concluded the consumer's complaint did not plausibly allege that a reasonable consumer would be deceived into believing that defendant's almond milk products are nutritionally equivalent to dairy milk based on their package labels and advertising. ${ }^{107}$ At stake are what the FDA calls "standards of identity," legally binding definitions of products to ensure

the lawsuit against Massachusetts. Iowa and Nevada were plaintiffs only in the suit against California. See id.; Indiana v. Massachusetts, 139 S. Ct. 859 (2019).

98. See Proposed Bill of Complaint at 1-2, Indiana v. Massachusetts, 139 S. Ct. 859 (2019) (No. 220149).

99. Id.; California, 139 S. Ct. at 859.

100. IOWA CODE $\S 135.16 \mathrm{~A}(3)$ (2019).

101. $§ 135.16 \mathrm{~A}(4)(\mathrm{b})$.

102. $§ 135.16 \mathrm{~A}(4)(\mathrm{c})$.

103. DAIRY PRIDE Act, S. 130, 115th Cong. § 2(8) (2017).

104. Use of the Names of Dairy Foods in the Labeling of Plant-Based Products, 83 Fed. Reg. 49103 (Sept. 28, 2018).

105. Use of Dairy Terms in the Labeling of Plant-Based Products, Docket Folder Summary, REgulations.gOv, https://www.regulations.gov/docket?D=FDA-2018-N-3522 [https://perma.cc/9RCK-A66K].

106. Painter v. Blue Diamond Growers, 757 F. App'x 517, 519 (9th Cir. 2018).

107. Id. 
consumers know what they are getting. ${ }^{108}$ The argument for stricter labeling rules is that consumers are not necessarily confused about where plant milk actually comes from, but the term "milk" evokes a nutritional profile that plant milk alternatives don't meet. ${ }^{109}$

In addition to a changing regulatory landscape, agricultural operators must contend with changing consumer tastes, which in turn drive market decisions. The law does not always keep up with the pace of change. Instead, consumers' preferences (expressed through marketing campaigns, pressure on companies, and direct ballot decisions) strongly impact how farmers produce agricultural commodities.

\section{ENVIRONMENTAL REGULATION}

All Indiana livestock farms are regulated by the Indiana Board of Animal Health and the Office of the Indiana State Chemist ("OISC"). ${ }^{110}$ Larger farms are subject to more extensive regulations; farms with over 600 pigs are also subject to Indiana Department of Environmental Management ("IDEM") regulations. ${ }^{111}$ These statutes and regulations include standards for siting, planning, permitting, inspecting, and operating a CFO. ${ }^{112}$ Approximately 94 percent of hogs in Indiana are on farms subject to oversight by IDEM. ${ }^{113}$ Additional federal rules apply to large CFOs (confusingly called CAFO-sized CFOs). ${ }^{114}$ Confined feeding operations are the most regulated livestock farms in Indiana.

Some contend there is not enough cropland to support large modern livestock operations, but here in Indiana that is not true. In 2017, farmers treated 791,000 acres of Indiana's cropland with organic manure fertilizer from livestock farms. ${ }^{115}$ Indiana has roughly 15,000,000 acres of farmland. ${ }^{116}$ For example, as of 2017, only 0.64 percent of the cropland in Hendricks County was needed for land application of the manure from existing livestock farms; thus, contrary to some anti-CFO groups' assertions, cropland availability is not a limiting factor for

108. See Conformity to definitions and standards of identity, 21 C.F.R. $\S 130.8$ (2019).

109. Painter, 757 F. App'x at 519.

110. See generally 345 Ind. Admin. Code 14 (2020); 355 Ind. Admin. Code 8-1-2 (2020).

111. IND. CODE $\S 13-11-2-40(1)$ (B) (2019) (defining "confined feeding operation" as any confined feeding of "at least six hundred (600) swine or sheep"); IND. CODE § 13-18-10 (2019); 327 IND. ADMIN. CODE 19 (2019).

112. See § 13-11-2-40; § 13-18-10; 327 Ind. AdMIN. CodE 19 (2020).

113. A Closer Look at Indiana's Livestock Industry, Ind. STATE DeP'T of AGRiculture, https://www.carrollcountyag.com/wp-content/uploads/2008/12/A_Closer_Look_at_Indianas_ Livestock_Industry-basic-information.pdf [https://perma.cc/29W4-BB77].

114. See Concentrated animal feeding operations, 40 C.F.R. $\S 122.23$ (2019).

115. 2017 Census of Agriculture, Indiana State and County Data, U.S. DEP'T OF Agriculture 40 (Apr. 2019), https://www.nass.usda.gov/Publications/AgCensus/2017/Full_ Report/Volume_1,_Chapter_1_State_Level/Indiana/inv1.pdf [https://perma.cc/A4AH-HFFL].

116. Id. at 7 . 
Indiana livestock farms. ${ }^{117}$

The RTFA is not, and should not be, a vehicle for changing environmental regulations. Some opponents have argued that today's livestock farms are a recent development, but Indiana began regulating confined feeding operations in 1971, and the EPA has administered federal regulations since $1974 .{ }^{118}$ The RTFA was passed in 1981 and first was applied to feeding hogs in confinement in 1987. ${ }^{119}$ There is nothing in the text of the RTFA to support the argument that a modern farm should fall outside of the Act's protections.

IV. ZONING

Finally, in addition to obtaining state permits, many agricultural operators must secure local county approval of a project before construction can begin. The State of Indiana has delegated certain powers to local municipalities, including the ability to create and enforce planning and zoning ordinances pertaining to land use. ${ }^{120}$

Planning and zoning seem, at least at first, like a purely local issue. This local control idea is often referred to as "Home Rule." But in most states, including here in Indiana, state (and federal) statutes limit a local government's power. These are the numerous exceptions to Home Rule.

First, a baseline. States generally follow "Dillon's Rule" (local governments only have the powers specifically granted to them by the state) or "Home Rule" (local governments generally have all powers necessary to govern their jurisdiction, except for those areas specifically prohibited by statute). Indiana is a Home Rule state. ${ }^{121}$ Local governments have all powers they need for effective government, except they do not have the powers listed in Indiana Code section 36-1-3-8(7). ${ }^{122}$ One of the big carve-outs is that local governments cannot regulate conduct already regulated by the state. ${ }^{123}$ What does this have to do with planning and zoning? In short, county commissioners cannot pass a zoning ordinance that

117. Indiana Confined Feeding Program, Ind. DeP'T of Envtl. Mgmt. 16 (May 30, 2017), https://www.in.gov/idem/cfo/files/about_cfo_presentation.pdf [https://perma.cc/RVA6-KKFL]. Indiana farmers may apply livestock manure to their fields to fertilize traditional row crops like corn and soybeans. Application is regulated by the OISC and IDEM. Farmers must apply at an agronomic rate based on manure and soil samples, observe setbacks from property lines and surface waters, and refrain from applying manure to frozen ground. 327 IND. ADMIN. CODE 19-14-1 et seq. (2019). Failure to follow these requirements can subject farmers to fines from the state agencies and could cause a farmer to lose his permit to operate.

118. See 33 U.S.C. § 1362(14) (2019); Ind. CodE ANN. § 13-1-5.7-1 (LexisNexis 1971); 39

Fed. Reg. 5704-06 (Feb. 14, 1974); 41 Fed. Reg. 11,458 (March 18, 1976).

119. Shatto v. McNulty, 509 N.E.2d 897, 900 (Ind. Ct. App. 1987).

120. IND. CODE $\S 36-7-2-2$ (2019).

121. § 36-1-3 et seq. (2019).

122. § 36-1-3-8(7) (2019).

123. § 36-1-3-8(7). 
conflicts with a state regulation. ${ }^{124}$ This problem arises over and over again with wind turbine farms, solar energy farms, livestock farms, and other agricultural developments.

For example, in 1991, the Fountain County Commissioners passed an ordinance establishing a local permitting procedure in addition to the state (IDEM) approval process. ${ }^{125}$ All the subjects of the ordinance were also covered by IDEM regulations, but some of the county ordinance requirements differed from IDEM's requirements. ${ }^{126}$ The county imposed greater setbacks, prohibited construction in migratory habitats, required different environmental protection systems, and eliminated some of the waivers available at the state level. ${ }^{127}$ The courts held the local ordinance was invalid because it contradicted the state regulation. ${ }^{128}$

On the other hand, in 2003, the courts upheld a LaPorte County ordinance that required landfills to obtain a letter of need from the local solid waste department. ${ }^{129}$ What was the difference? In the LaPorte County case, the Court found the need letter did not contradict any state regulations and served the purpose for which the state created solid waste departments. ${ }^{130}$ A court will strike down ordinances which are preempted under Indiana Code section 36-1-3-8(7). ${ }^{131}$

Once an agricultural producer determines whether a county zoning ordinance is preempted by a state or federal law, she must determine whether she needs any kind of local approval for her operation, and if so, what kind. In short, a variance is needed to diverge from the general developmental standards set by the county for the property at issue. ${ }^{132}$ A special exception is a property use that the municipality has decided to allow in that zone under certain circumstances. ${ }^{133}$ Some ordinances give the county board of zoning appeals a significant amount of discretion to decide whether to grant the special exception. ${ }^{134}$ Other ordinances limit the board of zoning appeals to consider a list of requirements that are black and white. An agricultural project also may require property to be rezoned to another zoning category (i.e. residential to agricultural or agricultural-I to agricultural-III). ${ }^{135}$ These are all possibilities facing an agricultural development,

124. § 36-1-3-8(7).

125. Triple G Landfills, Inc. v. Bd. of Comm'rs of Fountain Cty., 774 F. Supp. 528 (S.D. Ind. 1991), aff'd sub nom. Triple G Landfills, Inc. v. Bd. of Comm'rs of Fountain Cty., Ind., 977 F.2d 287 (7th Cir. 1992).

126. Id.

127. Id.

128. $I d$.

129. Bd. of Comm'rs of LaPorte Cty. v. Town \& Country Utils., Inc., 791 N.E.2d 249, 254 (Ind. Ct. App. 2003).

130. Id.

131. Id.

132. See Ind. CODE $\S 36-7-4-918.4$ (2019).

133. See $\S 36-7-4-918.2$.

134. See $§ 36-7-4-600$ et seq.

135. § 36-7-4-600 et seq. 
whether a confined feeding operation or a roadside produce stand.

One final local issue recently plaguing agricultural developments is that of the moratorium. In the past few years, counties have discussed, passed, or attempted to pass moratoria against confined feeding operations. ${ }^{136}$ A moratorium is a county's attempt to stop any development of the type in question. Whether the government calls it a ban or a hold or a moratorium, if the effect is to stop a certain type of development, it is a moratorium. A moratorium is, in effect, the same thing as a zoning ordinance amendment, so it must be enacted in accordance with Indiana Code section 36-7-4-600 et seq. ${ }^{137}$ Further, a county may not use a moratorium to preclude a pre-existing use. ${ }^{138}$ A county cannot enact a moratorium overnight - state law requires notice, publication of the proposed amendment, public hearings, and input from the county commissioners and the area plan commission. ${ }^{139}$

A moratorium, even if passed in accordance with state laws, must be reasonable. ${ }^{140}$ An open-ended ban with no time limits would likely be considered unreasonable and unenforceable. ${ }^{141}$ On the other hand, a limited moratorium put in place for a short time while the county considers new ordinance changes may pass muster. ${ }^{142}$ The U.S. Supreme Court considered a 32-month moratorium in Tahoe-Sierra Preservation Council, Inc. v. Tahoe Regional Planning Agency. ${ }^{143}$ The Court decided such a moratorium on development was not a per se taking under the Takings Clause of the U.S. Constitution. ${ }^{144}$ However, the Court noted that "it may be that" any moratorium lasting more than one year should be viewed with "special skepticism." facing recently enacted moratoria must consider the length of the ban, purpose, and complexity of issues facing the county to determine whether the moratorium is valid. ${ }^{146}$ In any event, a moratorium will not affect an application (for a

136. See, e.g. Terra Nova Dairy, LLC v. Wabash Cty. Bd. of Zoning Appeals, 890 N.E.2d 98, 101 (Ind. Ct. App. 2008).

137. IND. Code § 36-7-4-600 et seq.; Pro-Eco, Inc. v. Bd. of Comm'rs of Jay Cty., 956 F.2d 635, 638 (7th Cir. 1992) (overturning landfill moratorium); Sisters of St. Francis Health Serv's, Inc. v. Morgan Cty, Ind., 397 F.Supp.2d 1032, 1056 (S.D. Ind. 2005); City of Carmel v. Martin Marietta Materials, Inc., 883 N.E.2d 781, 787 (Ind. 2008).

138. New Albany DVD, LLC v. City of New Albany, 362 F. Supp. 2d 1015, 1024 (S.D. Ind. 2005).

139. IND. CODE $§ 36-7-4-602$ (2020).

140. New Albany DVD, LLC, 362 F. Supp. 3d, at 1021.

141. See generally $\S 36-7-4-602$.

142. See Tahoe-Sierra Pres. Council, Inc. v. Tahoe Reg'l Plan. Agency, 535 U.S. 302 (2002).

143. Id.

144. Id.

145. Id at 341.

146. See generally id. 
building permit, special exception, or other county permission) if the moratorium is passed after a complete application is submitted. ${ }^{147}$

In short, on top of nuisance lawsuits, environmental regulations, and changing consumer preferences, agricultural producers must be aware of and comply with local zoning ordinances.

147. IND. CoDE § 36-7-4-1109(c) (2020); see also Metro. Bd. of Zoning Appeals Div. III of Marion Cty. v. Traders Point Ass'n of Neighborhoods, 81 N.E.3d 1120, 1127 (Ind. Ct. App.), trans. denied sub nom. Three Mile Prop's, Inc. v. Traders Point Ass'n of Neighborhoods, 94 N.E.3d 701 (Ind. 2017). 